\title{
Antioxidative Effect of Pyruvate, Taurine and Melatonin, and Relationships of the Evaluation Methods on Boar Sperm Viability for In Vitro Storage
}

H. Y. Jang*, C. K. Park*, H. T. Cheong**, J. T. Kim**, H. K. Lee***, S. K. Im**** and B. K. Yang*

College of Animal life Science, Kangwon National University, Chuncheon 200-701, Korea*, School of Veterinary Medicine, Kangwon National University, Chuncheon 200-701, Korea**, Department of Genomic Engineering, Hankyong National University***, National Livestock Research Institute, RAD Suwon****

\section{돼지 정자의 체외보존에 있어 Pyruvate, Taurine 및 Melatonin의 항산화효과와 평가방법의 상관관계 분석 장현용* • 박춘근* - 정희태** . 김종택** . 이학교*** • 임석기**** . 양부근* 강원대학교 동물생명과학대학*, 강원대학교 수의과대학**, 한경대학교 생명공학부***, 농촌진흥청 축산과학원****}

\section{요 약}

본 연구는 돼지 정액의 체외보존에 있어 pyruvate, taurine 및 melatonin의 항산화 효과와 생존력의 평가방법간의 상관관계를 검토하고자 실시하였다. 돼지 정액의 체외보존시 항산화 효과를 평가하기 위하여 체외보존 신선정액에 pyruvate $(1 \mathrm{mM})$, taurine $(50 \mathrm{mM})$ 및 melatonin $(100 \mathrm{nM})$ 에 $\mathrm{H}_{2} \mathrm{O}_{2}(100 \mathrm{uM})$ 을 혼합첨가 및 항산화제 단독처리하여 체외에서 3 12시간까지 배양하면서 3시간 간격으로 정자의 운동 성, 정자의 원형질막의 완전성 및 지질 산화도를 측정하였다. 정자의 운동성은 항산화제 첨가구가 다 른 처리구에 비해 높은 결과를 나타내었고, Hypoosmotic swelling test (HOST) 방법을 이용한 정자의 원형질막 완전성에서도 운동성과 유사한 결과를 나타내었다. 정자의 원형질막의 지질산화도 검사에서 는 항산화제 첨가구와 무첨가구가 $\mathrm{H}_{2} \mathrm{O}_{2}$ 첨가구와 $\mathrm{H}_{2} \mathrm{O}_{2}$ 와 항산화제의 혼합 첨가구에 비해 낮은 결과 를 나타내었다. 또한 평가방법들 간의 상관관계에서는 운동성과 정자의 원형질막의 완전성에는 정의 상 관관계를 나타내었고, 정액의 성상검사 방법과 지질산화검사 방법에서는 부의 상관관계를 나타내었다.

본 실험의 결과는 정액희석액에 항산화제의 첨가는 정자의 운동성 및 정자의 원형질막 완전성을 증 가시키고, 정자의 원형질막의 지질산화도를 감소시키는 것으로 나타났다. 또한 정자의 원형질막의 완 전성 검사 $(\mathrm{HOST})$ 는 정자의 원형질막의 지질산화도 검사 및 운동성 검사를 대신하여 정자의 질적 평 가에 유용하게 이용될 수 있을 것으로 사료된다.

(Key words : Pyruvate, Taurine, Melatonin, Lipid peroxidation, Sperm characteristics)

\section{INTRODUCTION}

Preservation of fresh liquid semen for the artificial insemination (AI) is an important technique in pig reproduction. Maintaining the motility and fertility of spermatozoa during short-term storage typically less than 3 days at $17^{\circ} \mathrm{C}$ is an important consideration in the use of fresh liquid

Corresponding author : B. K. Yang, College of Animal life Science, Kangwon National University, Chuncheon 200-701, Korea.

Tel : +82-33-250-8623, Fax : +82-33-244-2532, E-mail : bkyang@kangwon.ac.kr 
semen in pig. Accurate evaluation of fresh semen preserved in vitro is also one of successful factors for AI industry in pig.

The molecular mechanism responsible for the sperm deterioration during in vitro storage is still unclear. Oxidative damage to spermatozoa during storage is a potential cause of the decline in motility and fertility in fresh semen. In recent years, the generation of reactive oxygen species (ROS) during in vitro storage has become a real concern because of their potential toxic effects at high levels on sperm quality and function (Sharma and Agarwal, 1996; Sikka, 2001).

Sperm has exposed to artificially produced ROS resulted in a significant increase in DNA damage (Duru et al, 2000). Oxidative stress has also been correlated with high frequencies of single and double DNA strand breaks (Twigg et al, 1998; Aitken and Krausz, 2001). One of the important factors to damage the pig sperm is related to the content of polyunsaturated fatty acids, which are susceptible to undergoing lipid peroxidation in the presence of the ROS (White, 1993). Efforts to improve the preservation of fresh semen and prevent the oxidative stress of spermatozoa have focused on alterations of extender as well as the addition of specific components supplemented to maintain the membrane integrity, motility and to decrease the lipid peroxidation.

Among the semen evaluation methods, motility, membrane integrity and lipid peroxidation of spermtozoal plasma membrane are commonly used to evaluate the sperm viability. These evaluation methods are also considered as the indices of sperm viability. But the relationships of these evaluation methods on boar semen in vitro storage were not yet compared.

The objective of this study was to examine the ability of antioxidants to improve the motility, membrane integrity and lipid peroxidation, and to compare the evaluation methods on viability of boar sperm during in vitro storage.

\section{П. MATERIAL AND METHODS}

\section{Semen preparation}

Sperm-rich fractions were collected from three breeds of boar at Youngsuh A. I. center. Just after collection, semen sample were diluted with Modena extender and transported to the laboratory at $17^{\circ} \mathrm{C}$ within 2 hrs. Semen was treated with antioxidants (Pyruvate $1 \mathrm{mM}$, Taurine 50 $\mathrm{mM}$ and Melatonin $100 \mathrm{nM}$ ) with or without hydrogen peroxide $(100 \mathrm{uM})$. The semen in each treatments was incubated for 3 to $12 \mathrm{~h}$ with $3 \mathrm{~h}$ intervals at $37^{\circ} \mathrm{C}$. All chemicals used in this study were purchased from Sigma-Aldrich (USA) unless otherwise stated.

\section{Semen evaluation}

\section{(1) Motility}

After gentle mixing, $20 \mathrm{ul}$ of semen sample was dropped in pre-warmed slide glass. Sperm motility was visually assessed by determining the percentage of motile spermatozoa under an inverted microscope with heated stage $\left(37^{\circ} \mathrm{C}\right)$ at $400 \times$ magnification. Each treatment groups were three replicates.

\section{(2) Hypo-osmotic swelling test (HOST)}

Sperm membrane integrity was evaluated by HOST. Briefly, a $100 \mathrm{ul}$ semen sample was added to $900 \mathrm{ul}$ of 150 mOsm hypo-osmotic solution (Na-citrate, 7.35g and fructose, $13.51 \mathrm{~g} / \mathrm{l}$ ), and then incubated for $30 \mathrm{~min}$ at $37^{\circ} \mathrm{C}$. Two hundreds spermatozoa per slide were observed for the changes associated with tail swelling and coiling. The percentage of membrane integrity was recorded for each group in number of spermatozoa with coiled tails per total number of spermatozoa examined. 
(3) Quantification of lipid peroxidation

Lipid peroxidation was measured by using the thiobarbituric acid (TBA) reaction for malondialdehyde. Semen treated with $0.01 \mathrm{M}$ sodium phosphate buffer (pH 7.4) containing 1.15\% (w:v) $\mathrm{KCl}$ was adjusted in $\mathrm{Ca}_{2}{ }^{+}$and $\mathrm{Mg}_{2}{ }^{+}$free D-PBS (Gibco, USA) to give a concentration to $20 \times 10^{6}$ spermatozoa $/ \mathrm{ml}$. For the increasing of lipid peroxide to malondialdehyde, lipid peroxidation was promoted using a combination of ferrous sulfate and sodium ascobate. Sperm suspension (1 $\mathrm{ml}$ ) was mixed with $10 \mathrm{ul}$ of $1 \mathrm{mM}$ ferrous sulfate and $10 \mathrm{ul}$ of $5 \mathrm{mM}$ sodium ascorbate, and then incubated for $1 \mathrm{hr}$ at $37^{\circ} \mathrm{C}$. The reaction mixture was added $250 \mathrm{ul}$ of $40 \%$ trichloacetic acid, held for $10 \mathrm{~min}$ at $0{ }^{\circ} \mathrm{C}$, and centrifuged $(2,500 \times \mathrm{g})$ for $10 \mathrm{~min}$. Supernatants $(1 \mathrm{ml})$ mixed with TBA were boiled with hot water for 10 min. The amount of malondealdehyde produced was quantified against a standard curve at 532 $\mathrm{nm}$ wavelength in spectrophotometer.

\section{(4) Statistical analysis}

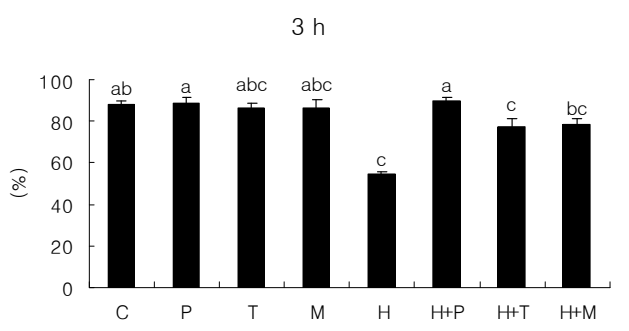

$9 \mathrm{~h}$

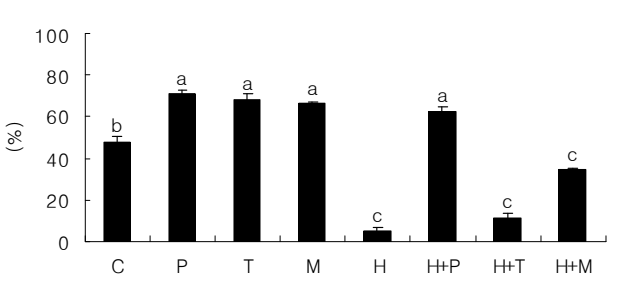

The effects of antioxidants and evaluation methods on sperm viability were analyzed by analysis of variance. Data analysis was performed using the SAS GLM procedure (SAS). Duncan's multiple range tests was used to compare mean value of each treatment groups. A P-value below 0.05 was considered significant. The treatments (semen sample plus antioxidants or semen sample plus antioxidants and hydrogen peroxide) and incubation times nested within the treatments and their interaction effects were included in the analytical model. The correlation coefficients among the evaluation methods were analyzed using the nested model; motility, membrane integrity and lipid peroxidation for sperm viability were considered.

\section{RESULTS}

The sperm motility and membrane integrity of boar semen treated by various antioxidants (pyruvate, taurine and melatonin) with or without hydrogen peroxide $\left(\mathrm{H}_{2} \mathrm{O}_{2}\right)$ were examined at 3,6 ,

$6 \mathrm{~h}$

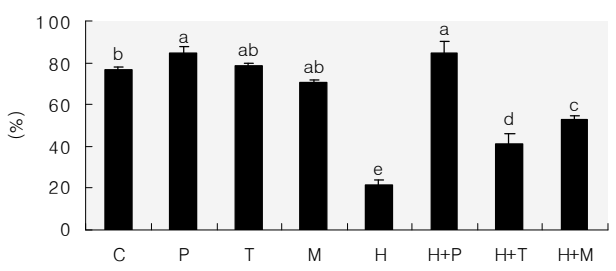

$12 \mathrm{~h}$

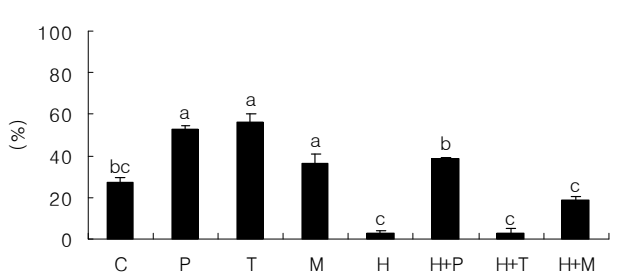

Fig. 1. Effects of antioxidants on motility for in vitro storage in boar semen.

$\mathrm{C}=$ control, $\mathrm{T}=50 \mathrm{mM}$ Taurine, $\mathrm{M}=100 \mathrm{nM}$ Melatonin, $\mathrm{P}=1 \mathrm{mM}$ Pyruvate, $\mathrm{H}=100$ uM Hydrogen peroxide, $\mathrm{H}+\mathrm{P}=100$ $\mathrm{uM}$ Hydrogen peroxide $+1 \mathrm{mM}$ Pyruvate, $\mathrm{H}+\mathrm{T}=100 \mathrm{uM}$ Hydrogen peroxide+50 mM Taurine, $\mathrm{H}+\mathrm{M}=100 \mathrm{uM}$ Hydrogen peroxide $+100 \mathrm{nM}$ Melatonin

a,b,c,d Different superscripts are significantly differ, $\mathrm{P}<0.05$. 
9 and $12 \mathrm{~h}$ from the incubation start at $37^{\circ} \mathrm{C}$ during in vitro incubation (Fig. 1 and 2).

No statistical differences were observed in motility among single antioxidant treatments for 3 h incubation, but antioxidants plus $\mathrm{H}_{2} \mathrm{O}_{2}$ except for pyruvate plus $\mathrm{H}_{2} \mathrm{O}_{2}$ were significantly decreased to control for $3 \mathrm{~h}$ incubation in sperm motility $(\mathrm{P}<0.05)$. Addition of antioxidants increased sperm motility over control at all time periods. In antioxidant plus $\mathrm{H}_{2} \mathrm{O}_{2}$ treatments, pyruvate with $\mathrm{H}_{2} \mathrm{O}_{2}$ significantly increased sperm motility when compared to any other treatments in irrespective
$3 \mathrm{~h}$

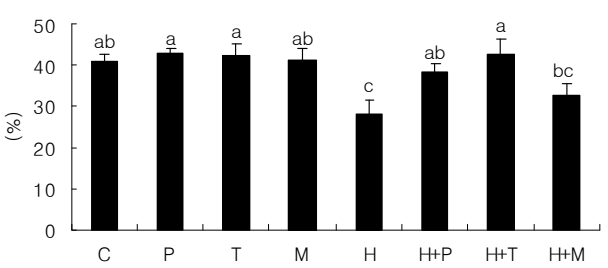

$9 \mathrm{~h}$

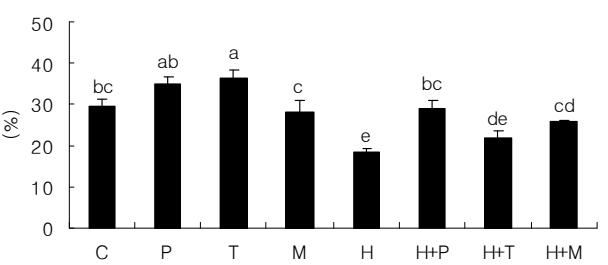

$6 \mathrm{~h}$

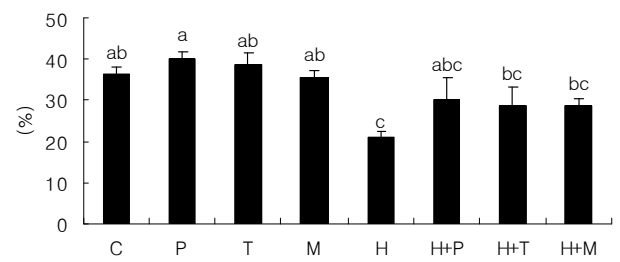

$12 \mathrm{~h}$

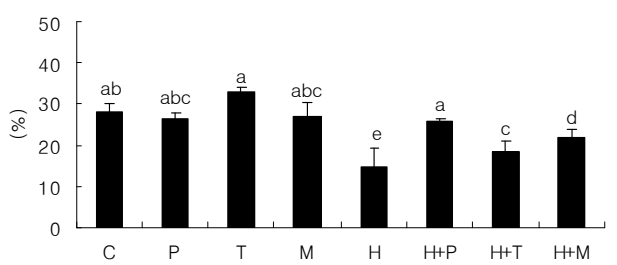

Fig. 2. Effects of antioxidants on membrane integrity for in vitro storage in boar semen. See Fig. 1 footnote for description of treatments a,b,c,d,e Different superscripts are significantly differ, $\mathrm{P}<0.05$.

$3 \mathrm{~h}$

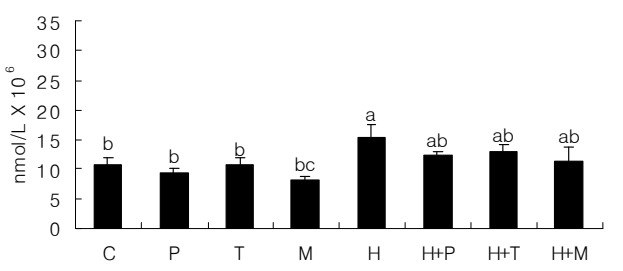

$9 \mathrm{~h}$

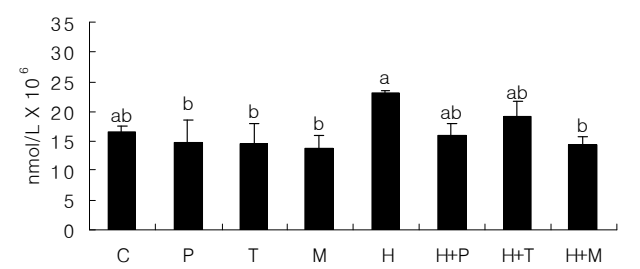

$6 \mathrm{~h}$

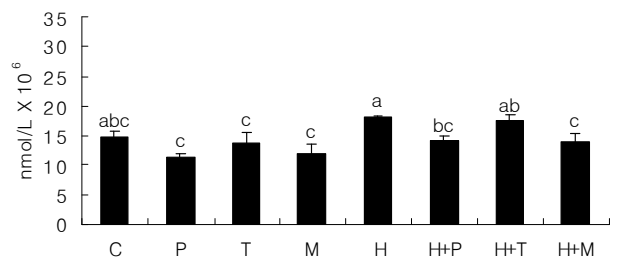

$12 \mathrm{~h}$

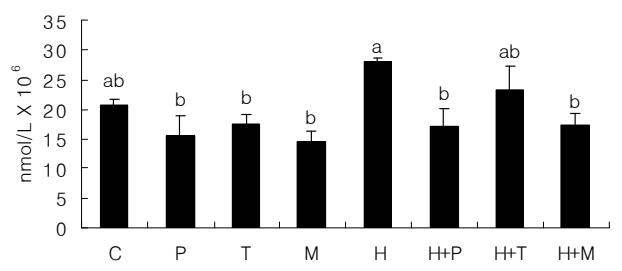

Fig. 3. Effects of antioxidants on lipid peroxidation of plasma membrane for in vitro storage in boar semen.

See Fig. 1 footnote for description of treatments

a,b,c Different superscripts are significantly differ, $\mathrm{P}<0.05$. 
to incubation times $(\mathrm{P}<0.05) . \quad \mathrm{H}_{2} \mathrm{O}_{2}$ treatment alone sharply dropped sperm motility between 3 and $12 \mathrm{~h}$ from the incubation start compare to any other group. Taurine plus $\mathrm{H}_{2} \mathrm{O}_{2}$ treatment also dramatically decreased sperm motility for 9 $\mathrm{h}$ in vitro incubation and both groups did not show the motile spermatozoa after $12 \mathrm{~h}$ incubation period.

Membrane integrity in single antioxidant treatments (pyruvate, taurine and melatonin) were not differs to control for 3 to $6 \mathrm{~h}$ incubation. However antioxidants plus $\mathrm{H}_{2} \mathrm{O}_{2}$ treatments were greatly reduced membrane integrity for 3 to $12 \mathrm{~h}$ when compare to control. For all incubation times, antioxidants supplement groups showed beneficial effects in sperm motility and membrane integrity compare to control, $\mathrm{H}_{2} \mathrm{O}_{2}$ treatment and antioxidants plus $\mathrm{H}_{2} \mathrm{O}_{2}$ group. The score of membrane integrity in pyruvate supplement group was the highest in all treatments in irrespective of all incubation times.

In lipid peroxidation measurement by TBA reactions of spermatozoal plasma membrane, malondialdehyde (MDA) level was $10.87 \mathrm{nmol} / \mathrm{L} \times$ $10^{6}$ in control and $9.50 \sim 11.97 \mathrm{nmol} / \mathrm{L} \times 10^{6}$ in antioxidant treatments and these levels were lower than those of antioxidant plus $\mathrm{H}_{2} \mathrm{O}_{2}$ or $\mathrm{H}_{2} \mathrm{O}_{2}$ treatment $\left(11.53 \sim 15.33 \mathrm{nmol} / \mathrm{L} \times 10^{6}\right)$ for 3 $\mathrm{h}$ incubation period. For $6 \mathrm{~h}$ of incubation, MDA levels in control, $\mathrm{H}_{2} \mathrm{O}_{2}$ alone and antioxidant plus $\mathrm{H}_{2} \mathrm{O}_{2}$ were higher than those in antioxidant treatments. Among antioxidant plus $\mathrm{H}_{2} \mathrm{O}_{2}$ treatments, MDA level in taurine plus $\mathrm{H}_{2} \mathrm{O}_{2}$ were higher than those of other treatments (melatonin $+\mathrm{H}_{2} \mathrm{O}_{2}$, pyruvate $+\mathrm{H}_{2} \mathrm{O}_{2}$ ) for 6 and $12 \mathrm{~h}$ incubation periods.

Relationships among evaluation methods for

Table 1. Correlation coefficients among different testing methods to evaluate the sperm quality in boar semen

\begin{tabular}{|c|c|c|c|c|}
\hline Treatments & Parameter & $\begin{array}{c}\text { Correlation } \\
\text { coefficient(r) }\end{array}$ & $\mathrm{P}$ value & Probabilities \\
\hline \multirow{3}{*}{$\mathrm{C}$} & MI vs LPO & -0.95 & 0.0001 & $* * *$ \\
\hline & MI vs Motility & 0.91 & 0.0001 & $* * *$ \\
\hline & LPO vs Motility & -0.80 & 0.0018 & $* *$ \\
\hline \multirow{3}{*}{$\mathrm{P}$} & MI vs LPO & -0.82 & 0.0010 & $* *$ \\
\hline & MI vs Motility & 0.53 & 0.0746 & NS \\
\hline & LPO vs Motility & -0.27 & 0.4004 & NS \\
\hline \multirow{3}{*}{$\mathrm{T}$} & MI vs LPO & -0.84 & 0.0005 & $* * *$ \\
\hline & MI vs Motility & 0.60 & 0.0387 & $*$ \\
\hline & LPO vs Motility & -0.34 & 0.2864 & NS \\
\hline \multirow{3}{*}{ M } & MI vs LPO & -0.92 & 0.0001 & $* * *$ \\
\hline & MI vs Motility & 0.59 & 0.0454 & $*$ \\
\hline & LPO vs Motility & -0.44 & 0.1507 & NS \\
\hline \multirow{3}{*}{$\mathrm{H}$} & MI vs LPO & -0.88 & 0.0002 & $* * *$ \\
\hline & MI vs Motility & 0.94 & 0.0001 & $* * *$ \\
\hline & LPO vs Motility & -0.81 & 0.0016 & $* *$ \\
\hline \multirow{3}{*}{$\mathrm{H}+\mathrm{P}$} & MI vs LPO & -0.68 & 0.0146 & $*$ \\
\hline & MI vs Motility & 0.56 & 0.0588 & NS \\
\hline & LPO vs Motility & -0.23 & 0.4635 & NS \\
\hline \multirow{3}{*}{$\mathrm{H}+\mathrm{T}$} & MI vs LPO & -0.85 & 0.0004 & $* * *$ \\
\hline & MI vs Motility & 0.69 & 0.0127 & $*$ \\
\hline & LPO vs Motility & -0.67 & 0.0167 & $*$ \\
\hline \multirow{3}{*}{$\mathrm{H}+\mathrm{M}$} & MI vs LPO & -0.85 & 0.0005 & $* * *$ \\
\hline & MI vs Motility & 0.62 & 0.0308 & $*$ \\
\hline & LPO vs Motility & -0.73 & 0.0073 & $* *$ \\
\hline
\end{tabular}

See Fig. 1 footnote for description of treatments

$\mathrm{MI}=$ Membrane integrity, $\mathrm{LPO}=$ lipid peroxidation

Significant level; * $\mathrm{P}<0.05$, ** $\mathrm{P}<0.01$, $* * * \mathrm{P}<0.001$, NS $=$ Not Significant 
sperm viability were investigated by motility, membrane integrity (MI) and lipid peroxidation (LPO, Table 1). Among evaluation methods, LPO vs motility or LPO vs MI were negatively correlated (-0.23 -0.81 and $-0.68 \sim-0.95)$, but MI vs motility was positively correlated $(0.53 \sim 0.94)$ in all treatments. The MI was negatively correlated largely with the LPO in all the treatments $(\mathrm{P}<0.001)$. The $\mathrm{MI}$ and the motility was positively correlated except for pyruvate with or without $\mathrm{H}_{2} \mathrm{O}_{2}$ treatment $(\mathrm{P}<$ 0.001). On the other hand, the LPO and motility were only negatively correlated with the treatments of control, $\mathrm{H}_{2} \mathrm{O}_{2}, \mathrm{H}_{2} \mathrm{O}_{2}+$ Taurine and $\mathrm{H}_{2} \mathrm{O}_{2}+$ Melatonin.

\section{DISCUSSION}

The generation of reactive oxygen species (ROS) during in vitro storage has a toxic effect at high levels on sperm quality and function (Aitken, 1994). Oxidative stress is one factor associated with decline in fertility during shortterm semen storage. Spermatozoa constantly face the oxygen $\left(\mathrm{O}_{2}\right)$ paradox in aerobic condition: $\mathrm{O}_{2}$ is required to support the life, but its metabolites such as ROS can modify cell functions, endanger cell survival (de Lamirande and Gagnon, 1995). Many kinds of antioxidants are available to protect spermatozoa against oxidants or oxidative stress. Antioxidants are classified into two types; one is enzymatic, including superoxide dismutase, catalase and glutathione peroxide / glutathione reductase. The other is non-enzymatic compounds, which are ascorbate, urate, a-tocopherol, pyruvate, glutathione, taurine, melatonin, hypotaurine and so on (Michiels et al., 1994). The addition of antioxidants to boar semen extender was improved the motility and membrane integrity in boar semen during in vitro storage (Funahashi and Sano, 2005). Equine spermatozoa produced $\mathrm{H}_{2} \mathrm{O}_{2}$ and the damaged spermatozoa produced an increased amount of $\mathrm{H}_{2} \mathrm{O}_{2}$. Abnormal or dead spermatozoa, particularly those with residual cytoplasm or mild piece abnormities, were capable of producing an elevated amount of $\mathrm{H}_{2} \mathrm{O}_{2}$ (Ball et al., 2001). Taurine has indirect antioxidant effects; it contributes to limit the deterious effect of ROS by neutralizing cytotoxic aldehyde the end-products of the peroxidation cascade reaction (Ogasawara et al., 1993). In our study, the addition of pyruvate, taurine and melatonin as an antioxidant was increased the motility and membrane integrity when compared to control regardless of incubation periods in vitro. In $\mathrm{H}_{2} \mathrm{O}_{2}$ plus antioxidants treatments, sperm motility and membrane integrity of $\mathrm{H}_{2} \mathrm{O}_{2}$ plus pyruvate increased to those of control $(\mathrm{P}<0.05$, Fig. 1, 2). Taurine has a weakly antioxidative effect compared to pyruvate treatment groups when occurred to the ROS by $\mathrm{H}_{2} \mathrm{O}_{2}$ in in vitro storage. This mechanism is not clear. This study agrees with the finding that pyruvate has an antioxidants property, when in vitro cultured with bovine embryo and human spermatozoa, preventing the peroxide-induced injury (Morales et al., 1999). Ogasawara et al. (1993) reported that taurine has indirect antioxidant property, which is in agreement with our study.

Exposure of sperm to ROS is associated with decreased fertility, and the formation of lipid peroxidation and DNA damage (Chen et al., 1997). The lipid peroxidation cascade is initiated when spermatozoa are attacked by ROS, which results in a loss of unsaturated fatty acids from plasma membrane and a decline in the motility and fertilizing ability of spermatozoa during storage (Aitken, 1995). Boar spermatozoa are particularly susceptible to oxidative attack by ROS because they contain large amounts of polyunsaturated fatty acid(White, 1993). ROS occurring regents such as $\mathrm{H}_{2} \mathrm{O}_{2}$ can reduce the antioxidant defence of spermatozoa and increase the peroxidation of plasma membrane (Griveau et al., 
1995). This study indicated that malondialdehyde (MDA) levels in antioxidant treatments were lower than those of any other treatments (control and antioxidants plus $\mathrm{H}_{2} \mathrm{O}_{2}$, Fig. 3). Our results consistent with those of Ball et al. (2001) that antioxidants act at various steps to either scavenge ROS directly or to prevent propagation of lipid peroxidation of cell membrane.

The ultimate goal of evaluating semen characteristics is to accurately predict its fertilizing potential which increases reproductive efficiency. The evaluation of sperm motility and spermatozoa membrane status is the most frequently assessed characteristics of sperm viability, although its correlation with fertility remains controversial (Januskauskas et al., 2000). Various tests are used to investigate the viability of boar sperm, including visual motility asessment, staining method using chemical compound, membrane integrity by HOST, lipid peroxidation of plasma membrane and so on. The visual motility assessment of boar spermatozoa, which widely used in practice, is a very subjective method. Also measuring the lipid peroxidation is one of efficient method to evaluate the sperm viability, it is time-consuming and complex method (Cerolini et al., 2000).

Currently one of the most widely used tests for evaluating spermatozoa membrane status, the hypoosmotic swelling test, is highly correlated with in vitro fertilization results using human spermatozoa (Perez-Llano et al., 2001).

The HOST is a relative simple and accurate assay being used to evaluate the functional integrity of spermatozoal plasma membranes (Jeyendren et al., 1984: Nie and Wenzel, 2001). The assessment of membrane function may be a useful indicator of the fertilizing ability of spermatozoa (Jeyendren et al., 1984). The used methods for evaluating the semen viability in this study were shown highly correlated (Table 1). Therefore, membrane integrity by HOST can substitute to examine the sperm viability for lipid peroxidation or visual motility assessment in pig.

The results of this study indicate that supplementation of antioxidants to the semen extender can improve the semen quality, and membrane integrity might be utilized to evaluate sperm quality instead of lipid peroxidation or motility.

\section{ABSTRACT}

The objective of this study was to investigate the anti-oxidative effects of pyruvate, taurine and melatonin on sperm characteristics (motility, membrane integrity) and lipid peroxidation (LPO) for in vitro storage of boar semen. Semen was treated with various antioxidants such as pyruvate $(1 \mathrm{mM})$, taurine $(50 \mathrm{mM})$ and melatonin $(100 \mathrm{nM})$ with or without $100 \mathrm{uM} \mathrm{H}_{2} \mathrm{O}_{2}$. Antioxidant treatments were significantly increased the sperm motility when compare to control group in all incubation periods $(\mathrm{P} \leq 0.05)$. Hypoosmotic swelling test (HOST), membrane integrity was similar to the result of motility. In lipid peroxidation measurement by TBA reactions of spermatozoal plasma membrane, malondialdehyde (MDA) level in control and antioxidant treatments were lower than those of antioxidant plus $\mathrm{H}_{2} \mathrm{O}_{2}$ or $\mathrm{H}_{2} \mathrm{O}_{2}$ treatment for 3 to $6 \mathrm{~h}$ incubation period. Relationships of evaluation methods for sperm viability were investigated by motility, membrane integrity and lipid peroxidation. Among evaluation methods, LPO vs motility and membrane integrity vs LPO were negatively correlated $(-0.23 \sim-0.92$ and $-0.68 \sim-0.85)$, but membrane integrity vs motility was positively correlated $(0.53 \sim 0.94)$ in all treatments.

These experiments indicate that supplementation of antioxidant to the semen extender can increase the sperm motility and membrane integrity and decrease the lipid peroxidation of spermatozoal plasma membrane. The HOST might be utilized to evaluate the sperm quality instead of lipid peroxidation or motility.

(Key words : Pyruvate, Taurine, Melatonin, Sperm characteristics, Lipid peroxidation (LPO)) 


\section{ACKNOWLEDGEMENT}

The authors are grant to the Institute of Animal Resource in Kangwon National University for helping in working the study.

\section{REFERENCE}

1. Aitken, R. J. 1994. A free radical theory of male infertility. Reprod. Fertil. Dev. 6:19-23.

2. Aitken, R. J. 1995. Free radicals, lipid peroxidation and sperm function. Reprod. Fertil. Dev. 7:659-668.

3. Aitken, R. J. and Krausz, C. 2001. Oxidative stress, DNA damage and the $\mathrm{Y}$ chromosome. Reproduction 122:497-506.

4. Ball, B. A., Medina, V., Gravance, C. G. and Baumbe, J. 2001. Effect of antioxidants on preservation of motility, viability and acrosomal integrity of equine spermatozoa during storage at 5 degrees C. Theriogenology 56:577-589.

5. Cerolini, S., Maldjian, A., Surai, P. and Noble, R. 2000. Viability, susceptibility to peroxidation and fatty acid composition of boar semen during liquid storage. Anim. Reprod. Sci. 58:99-111.

6. Chen, C. S., Chao, H. T., Pan R. L. and Wei, Y. H. 1997. Hydroxyl radical-induced decline in motility and increase in lipid peroxidation and DNA modification in human sperm. Biochem. Mol. Biol. Int. 43:291-303.

7. Duru, N. K., Morshedi, M. and Oehninger, S. 2000. Effects of hydrogen peroxide on DNA and plasma membrane integrity of human spermatozoa. Fertil. Steril. 74:1200-1207.

8. Funahashi, H. and Sano, T. 2005. Select antioxidants improve the function of extended boar semen stored at 10 degrees C. Theriogenology 63:1605-1616.

9. Griveau, J. F., Dumont, E., Renard, P., Callegari, J. P. and Le Lannou, D. 1995. Reactive oxygen species, lipid peroxidation and enzymatic defence systems in human spermatozoa. J. Reprod. Fertil. 103:17-26.

10. Januskauskas, A., Johannisson, A., Soderquist, L. and Rodriguez Martinez, H. 2000. Assessment of sperm characteristics post-thaw and response to calcium ionophore in relation to fertility in Swedish dairy AI bulls. Theriogenogy 53:859-875.

11. Jeyendran, R. S., Van der Ven, H. H., PerezPelaez, M., Crabo, B. G. and Zaneveld, L. J. D. 1984. Development of an assay to assess the functional integrity of the human sperm membrane and its relationship to other semen characteristics. J. Reprod. Fertil. 70:219-228.

12. de Lamirande, E. and Gagnon, C. 1995. Impact of reactive oxygen species on spermatozoa: a balancing act between beneficial and detrimental effects. Hum. Reprod., Suppl. 1:15-21.

13. Michiels, C., Raes, M., Toussaint, O. and Remacle, J. 1994. Importance of Se-glutathione peroxidase, catalase, and $\mathrm{Cu} / \mathrm{Zn}-\mathrm{SOD}$ for cell survival against oxidative stress. Free Radic. Biol. Med. 17:235-248.

14. Morales, H., Tilquin, P. and Rees, J. F. 1999. Pyruvate prevents peroxide-induced injury of in vitro preimplantation bovine embryos. Mol. Reprod. Dev. 52:149-157.

15. Nie, G. J. and Wenzel, J. G. W. 2001. Adaptation of the hypoosmotic swelling test to assess functional integrity of stallion spermatozoal plasma membranes. Theriogenology 55:1005-1018.

16. Ogasawara, M., Nakamura, T. and Koyama, I. 1993. Reactivity of taurine with aldehydes and its physiological role. Chem. Pharm. Bull. 41:21722175.

17. Perez-Llano, B., Lorenzo, J. L., Yenes, P., Trejo, A. and Garcia Casado, P. 2001. A short hypoosmotic swelling test for the prediction of boar sperm fertility. Theriogenology 56:387-398.

18. Sharma, R. K. K. and Agarwal, A. 1996. Role of reactive oxygen species in male infertility. Urology 48(6):835-50.

19. Sikka, S. C. 2001. Relative impact of oxidative stress on male reproductive function. Current Medicinal Chemistry 8:851-862.

20. Twigg, J. P., Irvine, D. S. K. and Aitken, R. J. 1998. Oxidative damage to DNA in human spermatozoa does not preclude pronucleus formation at intracytoplasmic sperm injection. Hum. Reprod. 1998;13:1864-71.

21. White, I. G. 1993. Lipids and calcium uptake of sperm in relation to cold shock and preservation. Repord. Fertil. Dev. 5:639-658.

(접수일자 : 2007. 10. 31. / 채택일자 : 2007. 12. 13.) 